This item was submitted to Loughborough's Research Repository by the author.

Items in Figshare are protected by copyright, with all rights reserved, unless otherwise indicated.

\title{
Pushing regional studies beyond its borders
}

PLEASE CITE THE PUBLISHED VERSION

https://doi.org/10.1080/00343404.2019.1672146

PUBLISHER

Taylor \& Francis (Routledge)

VERSION

AM (Accepted Manuscript)

PUBLISHER STATEMENT

This is an Accepted Manuscript of an article published by Taylor \& Francis in Regional Studies on 22 October 2019, available online: http://www.tandfonline.com/10.1080/00343404.2019.1672146.

\section{LICENCE}

CC BY-NC-ND 4.0

\section{REPOSITORY RECORD}

Harrison, John, Mercedes Delgado, Ben Derudder, Isabelle Anguelovski, Sergio Montero, David Bailey, and Lisa De Propris. 2019. "Pushing Regional Studies Beyond Its Borders". figshare. https://hdl.handle.net/2134/9914057.v1. 


*** Accepted for publication in Regional Studies. DOI:
https://doi.org/10.1080/00343404.2019.1672146

\title{
Pushing regional studies beyond its borders
}

John Harrison ${ }^{1}$, Mercedes Delgado ${ }^{2}$, Ben Derudder ${ }^{3}$, Isabelle Anguelovski ${ }^{4}$, Sergio Montero ${ }^{5}$, David Bailey and Lisa De Propris ${ }^{6}$

\footnotetext{
${ }^{1}$ Geography and Environment, Loughborough University, UK. Email: j.harrison4@lboro.ac.uk

${ }^{2}$ Copenhagen Business School, Denmark; MIT Innovation Initiative, US. Email: md.si@cbs.dk

${ }^{3}$ Department of Geography, Ghent University, Belgium. Email: ben.derudder@ugent.be

4 ICREA (Institució Catalana de Recerca i Estudis Avançats) Research Professor, Universitat Autònoma de Barcelona (UAB). Email: isabelle.anguelovski@uab.cat

${ }^{5}$ Centro Interdisciplinario de Estudios sobre Desarrollo (CIDER), University of Los Andes, Colombia. Email: s.montero@uniandes.edu.co

6 Birmingham Business School, University of Birmingham, UK. Email: d.g.bailey@bham.ac.uk and l.de propris@bham.ac.uk
}

\begin{abstract}
:
This paper explores how we push the field of regional studies beyond its present institutional, conceptual and methodological borders. It does this from five perspectives: innovation and competitiveness, globalisation and urbanisation, social and environmental justice, local and regional development, and industrial policy. It argues that the future of regional studies requires approaches which in combination result in the pushing on (by creating), pushing off (by consolidating), pushing back (by critiquing) and pushing forwards (by collectively constructing) the field.
\end{abstract}

Keywords: regional studies, competitiveness, urbanisation, social and environmental justice, local and regional development, industrial policy

\section{PUSHING ON: REGIONAL STUDIES AND THE BIG GLOBAL CHALLANGES}

Regional Studies recently celebrated its $50^{\text {th }}$ anniversary. In this article we asked five leading researchers in their respective fields to reflect on recent developments in regional studies and challenged them on the question of how we push the field of regional studies on 
beyond its present institutional, conceptual and methodological borders. The overarching aim is to stimulate debate around the current state of regional research, and how this is sitting in the face of the big global challenges. This is obviously a highly selective exercise given the considerable breadth and depth of regional research. Here we present five perspectives that reflect topics prominent in regional studies over the years and likely to be a central feature in the years ahead: innovation and competitiveness (Delgado), globalisation and urbanisation (Derudder), social and environmental justice (Anguelovski), local and regional development (Montero), and industrial policy (Bailey and De Propris). Each contribution reflects on the current state of the art by identifying the strengths and weaknesses present in each approach before offering a vision for pushing regional studies on, and the opportunities and challenges that lay ahead.

\section{PUSHING REGIONAL STUDIES BEYOND ITS BORDERS I: AN INNOVATION AND COMPETITIVENESS PERSPECTIVE}

The competitiveness of a nation or a region is defined as the ability to compete regionally and globally in a way that supports good jobs and high living standards (Porter, 2000). Competitiveness depends on the ability of regions (their ecosystems of people, firms, industry clusters, and institutions) to manage and respond to all sort of shocks (economic, technological, political, institutional, organisational, natural disaster, among others). A key role of regional studies is to inform companies, regions, and nations how best to compete and collaborate to drive innovation and competitiveness, and ultimately, inclusive and resilient prosperity.

Strengths. Regional research has many strengths as reflected by the increasing number of scholars and practitioners in this field. It is multi-disciplinary and includes economics, geography, strategy, urban planning, design and architecture, and physics, among other fields, resulting in a multitude of important research questions and novel methods. It allows for multi-level analysis (people, organisations, industry clusters, places, cities, regions, and countries), and learns by benchmarking across regions. Furthermore, the regional context is increasingly important to innovation as manifested in firms' location strategies designed to access talent, suppliers, and other resources to scale up and accelerate innovation. One example is Amazon's recent location choice for its second headquarters (HQ2). It involved the selection of 20 candidate cities, all of which had specialisation in at least one of the three industry clusters relevant to the firm: Information Technology, Distribution and Ecommerce, and Communications Equipment and Services.. ${ }^{i}$

Weaknesses. There are some long-lasting and increasingly limiting weaknesses in this field. One is its obsession with manufacturing, and the meagre attention paid to the large and heterogeneous services sector. In today's economy, innovative activity and high-wage jobs are concentrated in suppliers selling inputs to businesses (i.e. the "supply chain economy"). 
Many of these firms are suppliers of traded services like cloud computing, Al, enterprise software, logistics, engineering and design services (Delgado and Mills, 2018). There is an evolution occurring from manufacturing towards supply chain services by large incumbent firms (e.g. IBM, Intel, Cisco) and by many young firms that we cannot ignore. Another weakness is that studies often lack integration of network analysis (mapping socioeconomic linkages among people and organisations) with industry cluster analysis (mapping the comparative advantages of regions as manifested in the specialisation in related industries and firms and support institutions). This limits our ability to inform regions and firms in developing strategies for innovation and entrepreneurship. To date, there has also been a poor integration between economic geography and strategic management (Porter, 2000; Delgado, 2018). The examination of the interaction between firm strategy and the attributes of locations might help firms to find the best strategic positioning in their locations and thus to improve their competitive advantage and resilience. For example, we could help start-ups improve the fit between their strategy and location attributes, and better engage with innovation ecosystems. The fusion of network, cluster, and strategic management analysis represents a broad research opportunity for our community.

Vision. To push regional studies beyond its borders, my vision is to focus on mapping and solving imbalances in industry clusters and their regional innovation ecosystems. The goal of this research would be to inform firms and policymakers in order to build more resilient and inclusive competitiveness. Regions can face many imbalances, including: lack of Science, Technology, Engineering and Math (STEM) skills; missing suppliers of specialised inputs; low innovation-driven start-up activity; gender gaps in innovation (e.g. lack of female inventors and entrepreneurs; Delgado and Murray, 2019); disconnected inner cities, small-cities, and rural areas (Delgado, 2018); weak support institutions; and lack of sustainability due to irresponsible use of natural resources. These imbalances could be amplified during crises and make regions very vulnerable.

Opportunities and Challenges. To implement this vision, we could map everything. But the challenge is that regions are complex systems. Thus, it is not about mapping per se, but about deciding what to map, and why and how to identify problems and solutions that reduce imbalances which could put regions at risk. To do this, I propose three types of frameworks and tools:

(i) Those to identify and measure imbalances: they will focus on mapping the indicators we are interested in (e.g. STEM skills or the ratio of female inventors across locations);

(ii) Those to reduce and resolve the imbalances: they will focus on catalysing change by identifying who the catalysts are - people, firms, and institutions - and how they function (e.g. universities can be catalysts for change in female inventor inclusivity because they train most STEM students); and

(iii) Those to choose and assess among alternative policy initiatives to solve the problems: they will focus on twinning cities and their regions in some 
dimensions, so that we can create the counterfactual (what would have happened in the city without the intervention) and compare performance before versus after the intervention. This would also allow cities and regions to "time travel" and learn from the policy initiatives implemented in other locations in the past.

This type of research could improve the resilience and inclusivity of prosperity. As volatility has increased in most economies and their regions, it is more important than ever to build, strengthen and exploit the comparative advantages of regions in a way that improves sustainable prosperity. Scholars and practitioners in regional studies have a unique opportunity to inform this goal.

\section{PUSHING REGIONAL STUDIES BEYOND ITS BORDERS II: A GLOBAL URBAN PERSPECTIVE}

This perspective focuses on the main debates surrounding two global urban concepts increasingly prominent in regional studies: world city networks (WCNs) and polycentric urban regions (PURs). WCN is a concept used for studying inter-city connections at the global scale (Derudder and Taylor, 2018). A recurring finding in WCN research is that there are stark regional orderings to these inter-city connections (Rozenblat, 2010) and, in addition to the well-documented dominance of cities such as New York and London, there are overlapping and porous world-regional patterns within these connections (Taylor et al., 2013). Research on PURs, a concept used for studying regions characterised by synergies between proximate and densely connected urban centres, is increasingly providing the analytical lens for analysing new, emerging regional geographies.

Strengths. An obvious strength of these literatures is that they help make sense of developing empirical realities. PURs have become - at least in Europe - a day-to-day reality for many people (Meijers et al., 2016), while Mahutga et al. (2010) identify the mechanisms for the noticeable upward mobility of cities located in Pacific Asian region in the WCN. However, the key strength of both literatures is that they provide robust antidotes to statecentric analyses of a globalising world: they credibly tackle meta-critiques of much of the social sciences treating states as the self-evident spatial containers of social, economic and political processes (Taylor, 1994). In a globalising world economy, large-scale city-regions become increasingly important because of possibilities for heightened geographic differentiation and locational specialisation (Scott, 2019). This shift towards a global economy centred on city-regions is of course but one part of more complex rescaling processes characterised by changing interfaces between cities, regions, and states (Brenner, 2019). Nonetheless, the specific and imaginative attention being paid in WCN/PUR research to what makes some cities and regions so salient in today's global economy justifies the central position of these concepts within regional studies. At the same time, both literatures' strengths go well beyond their conceptual and empirical significance. The lack of 
commonly available data sources to analyse inter-city connections at the global and the regional scale, a major analytical asset is that they have facilitated innovative approaches in terms of data gathering and methodologies (e.g. Salvini and Fabrikant, 2016; Zhang et al., 2018).

Weaknesses. Despite enriching regional studies, both literatures struggle with conceptual vagueness, epitomised by the presence of a plethora of related yet sometimes slightly different concepts. As Taylor and Lang (2004) point out, such diversity is helpful in the sense that the urban and regional world is inherently complex and therefore it is appropriate that it should be described from diverse vantage points. However, the continued positing of new terms, concepts and approaches is not always conducive to a credible understanding of what is going on: there is a degree of analytical disintegration that may start hindering debate (Paasi et al., 2018). Second, the geographical unevenness in the production of 'theory' looms large (Roy, 2009). Both WCN and PUR research originally developed as bodies of knowledge from and about a select group of cities and regions from the Global North. Often, cities and regions from other parts of the world are thereupon evaluated as 'cases', often by simply copying conceptual frameworks and empirical approaches. The detrimental effects of this are well documented for the WCN literature (Robinson, 2002), but similar issues abound in PUR research. For example, recent research into regional development in China often scrutinises regions such as the Yangtze River Delta using the PUR framework (e.g. Li and Phelps, 2017). However, given a very particular space-economy in which urbanisation and regionalisation unfolds (Zhang and Peck, 2016; Wu, 2016) and the very different scale of Chinese regions, it is unclear whether straightforward parallels with the likes of Randstad Holland are sufficient to fit it into the same conceptual box. The issue here is not simply whether such an (implicitly) comparative exercise is relevant, but more fundamentally about power hierarchies in terms of who makes, and what counts as, 'theory' as we make sense of cities and regions.

Vision. Based on the above, a key element to both literatures retaining their vibrancy is that they need to preserve their strengths while at the same addressing their limitations. In this context, much can be gained from an engaged and rigorous effort to think through how cities and regions can be effectively compared. Of course, calls for the need of suitable comparative frameworks that challenge urban and regional theories that treat Global North experiences as the norm are far from new. However, Peck (2015) notes that despite repeated calls for more substantively comparative modes of urban and regional theorymaking, a worldlier comparative theorisation has yet to be realised. In addition to the need for effectively achieving adequate comparative methodologies and constructive dialogue across theoretical traditions and geographical contexts, Peck emphasises the need to double down on theoretical interrogation of pan-urban and regional processes and patterns from a relational perspective. Recent attempts to de-stretch concepts to make their exact meaning clearer (Van Meeteren et al., 2016a/b) and further consolidate comparative approaches (Robinson, 2016b) offer great potential to stress-test and re-situate the explanatory value of 
concepts such as PUR and WCN. This may be a difficult and at times uncomfortable exercise, but it is a vision that holds great potential when carried out in the spirit of engaged pluralism which encourages us "however much we are committed to our styles of thinking (to be) willing to listen to others without denying or suppressing the otherness of the other" (Barnes and Shepard, 2010, p. 194).

Opportunities and Challenges. Perhaps because of their success both literatures risk becoming increasingly self-referential. In the case of WCN, for example, Van Meeteren and Bassens (2016) point out that a singular focus on networks and connectivity may veil dynamics that lead to internal stratification and hierarchy between world cities and their constitutive outside. Complementing now-dominant network-based analyses with territorial, scalar and place-based abstractions may result in a richer literature. In the case of PUR research, it can be noted that it is in principle part of a much broader research agenda dealing with the resurgence of regions in terms of institution building, identity formation, emerging spaces of democracy and citizenship. Nonetheless, much of the literature on PURs increasingly focused on issues of economic development and competitiveness. There are therefore ample opportunities to reconnect with other longstanding literatures on the resurgence of the region, but also with a range of emerging literatures exploring the sociopolitical dimensions of the widening gap between well-connected cities and regions and those at the fringes (Rodríguez-Pose, 2018; Guilluy, 2016). Second, there is the thorny issue of the often-conflicted relation with policy. The PUR framework is not only an analytical agenda, but increasingly a normative policy framework. However, according to Davoudi (2007), there is a tension between both in that there is often a purposeful definitional ambiguity surrounding PURs in planning circles: every actor involved in the planning process can and does attribute its own interpretation to it. Meanwhile, ranking cities in terms of their global connectivity as sometimes happens in WCN research chimes worryingly with a neoliberal-auditing-cum-benchmarking policy culture. Distorted versions of this concept often transfer into policy areas as aspirational models and standards for urban-economic strategies. Both examples show that there are, in principle, major and untapped opportunities for connecting this research with policymaking, but that these connections risk being trivial and formulaic at best, and instrumental and problematic at worst. In any case, it seems clear that finding ways to navigate this and some of the other conundrums will shape these literatures' prominence within new regional studies thinking.

\section{PUSHING REGIONAL STUDIES BEYOND ITS BORDERS III: A SOCIAL AND ENVIRONMENTAL JUSTICE PERSEPCTIVE}

As cities disproportionally contribute to climate change and are directly impacted by its impacts, they are often seen as the laboratory of climate mitigation and adaptation experiments. Yet, interventions on the ground still poorly incorporate equity and justice considerations for the most socially vulnerable residents, their needs, and their identities, 
and much of their work on such matters remains to be evaluated (Bulkeley et al., 2014; Shi et al., 2016).

Strengths. Cities are responsible for $75 \%$ of global CO2 emissions. At the same time, the concentration of residents, buildings, infrastructure, and natural resources in cities make them particularly exposed to risks and impacts. Climate impacts are particularly acute for the 828 million low-income residents living in informal settlements (Intergovernmental Panel on Climate Change, 2014). Currently, new municipal and/or metropolitan priorities around climate adaptation and resilience are emerging against a backdrop of urban segregation, spatial inequality, and the uneven application of land use planning and development regulations (Anguelovski et al., 2016). In recent years, we can also observe a shift towards solutions that incorporate green infrastructure and nature-driven solutions that combine adaptation and mitigation under a no-regret and benefit-maximisation approach (Meerow and Newell, 2017). For instance, Quito's reforestation and ecosystem restoration program attempts to achieve REDD+ objectives while addressing landslides and improving biodiversity (Anguelovski et al., 2014). Many municipal and/or metropolitan programs hold the value of being underpinned and supported by a favourable global policy context, such as the 2016 Urban Agenda for Europe, 2016 New Urban Agenda, and SDG 11 on sustainable cities and communities. The New Urban Agenda, for example, advocates for providing basic services for all citizens, strengthening resilience in cities to reduce the risk and the impact of disasters, taking action to address climate change by reducing GHG emissions, improve connectivity and support innovative and green initiatives, and promote safe, accessible and green public spaces.

Weaknesses. For all of this, urban interventions tend to take place in a context of unchallenged urban spatial and economic growth, which many have linked to increasing carbon emissions and climate risks (Anguelovski et al., 2016, Romero-Lankao et al., 2018). For instance, a central premise for Europe's Urban Agenda is to stimulate growth, liveability and innovation in the cities of Europe. There is thus an inherent, untreated conflict between unlimited urban and economic growth (driven by tourism, real estate investment, technouniversity research and innovation complexes) agendas and what we could call transformational urban climate agendas, through which the drivers of climate changes are clearly acted upon (Nightingale et al., 2019). Second, urban climate interventions often take place within into a sectoral and segmented environmental/green planning practice, where other essential city departments of agencies - housing, economic development, transport are often left aside. Radical planning agendas are also often invisibilised or defeated by rational, technocratic and communication-focused planning approaches which, by nature, advocate for an ideal 'public good' while deemphasising asymmetric power dynamics and conflict over resources (Anguelovski et al. 2016). Yet, traditionally, lower-income and minority residents have suffered to a greater extent from environmental toxics, climate risks, and poor access to green space/infrastructure in comparison with white and higherincome residents (Anguelovski et al., 2019). For instance, in the US, Los Angeles County 
Department of Public Health revealed that in 2016 56\% of African Americans and $50 \%$ of Latinos resided in communities with less park space per capita in comparison with only $27 \%$ of white residents. "i Such inequities are particularly impactful since high residential exposure to green spaces is associated, among others, with an $8 \%$ lower risk of all-cause mortality (Gascon et al., 2016) and recent urban climate action puts green space and infrastructure at the centre of new resilient interventions.

Vision: In contrast, sustainable, green, and just urban agendas would place health and equity at the centre of climate action as to create green cities for all rather than green cities as enclaves of environmental privilege for a few (Anguelovski et al., 2018). They would also acknowledge that minorities and lower-income residents tend to face a quadruple form of injustice in regard to climate change: They are traditionally those who have least contributed to climate change and yet the most exposed to its effects, with the least resources to adapt and in fact, and most likely to be displaced by climate infrastructure and investments. Cities would thus pursue deliberate transformative actions to increase the scale of interventions, address drivers of socio-spatial vulnerability, and fundamentally alter economic growth paradigms and class relations (Pelling et al., 2015). One example of such a vision is embodied in the Barcelona Superblock program. iii Embedded in the Municipal Mobility Plan, the program brings together climate mitigation (emission reduction) and adaptation (heat island) goals while altering existing mobility patterns, enhancing access to public/open spaces, and reducing noise pollution. It also proposes new urban development path and city visions of a just and green city, is permeated by larger discourses and policies questioning economic and spatial growth, and incorporates an equality and equity-driven approach - with superblocks built throughout the city and providing benefits for different classes of residents.

Opportunities and Challenges. Innovative climate interventions will need to be bold to address growth while confronting social and health inequalities and avoid shifting risks to historically marginalised groups. They will need to overcome practices by which urban economic actors may be employing the rhetoric of climate resilience to exacerbate or maintain speculative, exclusionary, or unsustainable practices that might worsen existing injustices linked to land use development and infrastructure (Sovacool et al., 2015). As a result, tradeoffs associated with the uneven distribution of adaptation costs and benefits should be more clearly visibilised and evaluated during climate action planning and implementation (Pelling et al., 2015). For example, in 2018 Boston's mayor introduced the resilient Boston Harbour Plan ${ }^{i v}$ which associates green infrastructure and nature-based solutions to address climate impacts together with inclusivity and wealth creation for racial and ethnic minorities. Yet, Boston's plan overlooks climate gentrification, or the risk of midto long-term displacement of socially vulnerable residents due to climate adaptation planning and infrastructure (Anguelovski et al. 2016). Its implementation will also require new financing resources and tools that the city is currently assembling. However, as local media, researchers, and activists have already denounced, if the city turns to private 
developers to finance green adaptation, this might work against the interest of the middle and working class and minorities, as has historically occurred in Boston - and elsewhere when private development takes control of urban planning and infrastructure development. ${ }^{v}$ Put differently, green infrastructure planning for climate change needs to incorporate financing schemes that will ensure the protection of existing social and public housing stocks and build new permanent affordable housing in the vicinity of new climateresilience infrastructure.

In sum, integrating the concerns, needs, and vulnerabilities of social groups that might be less vocal or visible should be at the core of building climate-responsive, green, and just cities. Otherwise, green amenities can create conditions - at inception or over time - for the social and spatial exclusion of the most socially and racially vulnerable residents, their livelihoods, and practices and become Green LULUs (Green Locally Unwanted Land Uses) in racially mixed and low-income neighbourhoods (Anguelovski, 2016). In that context, directing urban climate action in ways that prioritises the well-being and health of all residents and controls speculative, growth-oriented development should be at the centre of urban climate planning practice.

\section{PUSHING REGIONAL STUDIES BEYOND ITS BORDERS IV: A LOCAL AND REGIONAL DEVELOPMENT PERSPECTIVE}

A key question in debates around local and regional development is why (and how) certain cities and regions do better than others in terms of development? Increasingly we need to consider this in a postcolonial that seeks to generate not only place-sensitive policy but also place-sensitive theory. Here this is done from a Latin American perspective for illustrative purposes.

Strengths. Local and regional development studies have generated a rich and interdisciplinary discussion in recent years, including the New Economic Geography (Krugman, 2011), institutionalist perspectives (Pike et al., 2016), Evolutionary Economic Geography frameworks (Martin \& Sunley, 2015) or post-development debates (Escobar, 2008). These approaches have contributed to a more sophisticated and place-based understanding of what makes certain cities and regions develop and moved the field beyond purely economic and growth explanations. The second strength is that local and regional development still generates much interest among academics but also among policymakers, planners and local and regional leaders. Increasing urbanisation rates and decentralisation processes in recent decades have meant that there are more cities, mayors, planners and local leaders demanding explanations and policies to promote local economic development, particularly in the Global South. But the other reason behind this interest is the persistence of interregional uneven development. For instance, the 2008 global financial crisis affected Europe's poorer regions, or what Rodríguez-Pose (2018) has called the "places that don't matter," more so than richer regions. In Latin America, interregional disparities have also 
persisted and, indeed, increased in recent years despite significant decreases in poverty levels. In Colombia, for instance, poverty has decreased from 30\% in 2010 to 18\% in 2016. Yet in 2016, while $12 \%$ of those living in urban areas were considered poor, the figure rose to $45 \%$ for those in rural and peripheral regions (Montero, forthcoming). So, in addition to poverty reduction, interregional and urban-rural disparities are still an important theoretical and public policy problem not only in Latin America but in most countries around the world.

Weaknesses. While the persistence of interregional uneven development has created an interest in local and regional studies, we should also see this as a weakness, or actually, a failure of local and regional development policy and theory. In Latin America, politicians often argue that the problem is that we have not implemented regional policies. And yet, many local and regional development policies have been applied in Latin America since the 1940s (Chapple et al., 2012). The problem is not that there are no policies but rather the way that policies were implemented and the theory behind those policies. Part of the problem behind local and regional development policy in Latin America has been that much of the theory has been focused on large urban agglomerations in the Global North as nodes of innovation and competitive advantage that connect territories to global value chains. Yet, this framework often fails to address the challenges of smaller cities and peripheral regions in both the global North and the South, which represent most of the urban population (Montero \& Chapple 2018). This is not only a worrying gap in the literature, but also as a problem for practitioners and planners in small and medium-sized cities. Theories and policies that seek to support the ascent of global city-regions, such as export zones, hightech clusters, and creative talent attraction strategies do not transfer at all well to the economic development reality of smaller cities and peripheral regions. For example, given the current obsession to replicate international "best practices," we have seen an explosion in Latin American cities that want to become Silicon Valley, both in large and smaller cities. None of them has worked so far.

Vision. We need to better conceptualise how development occurs in small and mediumsized cities, how innovation takes place in peripheral regions and how these processes take place in the global South. This requires moving beyond the urban/rural and North/South divides in which local and regional economic development debates have often been based and engaging more with postcolonial thinking in urban and regional studies - in English (Robinson \& Roy, 2016) but also in other languages (Ramírez-Velázquez \& Pradilla Cobos, 2015). There are also interesting debates around the making of diverse economies (Roelvnik et al., 2015), feminist geography (Gibson-Graham, 2016) and indigenous and race studies (Yashar, 2015) that can benefit local and regional development studies. For example, if we want to think about the relationship between leadership and local development in Latin America, we cannot ignore the systematic profiling and killing of black and indigenous social leaders in Colombia. This vision also includes moving beyond the idea that exchanging and replicating international local and regional "best practices" is the solution for development problems (Montero 2019). Here, recent authors in economic geography and regional studies 
that have argued to think about place-based or place-sensitive policies are very welcome. But, to have place-sensitive policies we need place-sensitive theory that will help us explain what are the different factors that affect local and regional development beyond Eurocentric approaches.

Opportunities and Challenges. One of the main opportunities and challenges for regional studies is to develop place-sensitive theory that is more attuned with the institutional diversity of different cities and regions. But how do we theorise about processes of local and regional development taking place in different places without falling into the trap of the particular (Scott \& Storper, 2015) or the universal (Robinson \& Roy, 2016)? There is great potential in theory-generating comparisons, that is, comparisons that do not emphasise the empirical differences of cases but those that look for similarities between cases to challenge existing theories. This is what Jennifer Robinson (2016a) has called looking for 'repeated instances'. Identifying those repeated instances between cases is a form of abstraction or theorisation that can be especially helpful for those doing research in the Global South, as Global South cities and regions are often reduced to the empirical, to a case study that needs to be explained against a theory originated in the North. An example of this kind of theory-generating comparison is Fragile Governance and Local Economic Development: Theory and Evidence from Peripheral Regions in Latin America (Montero \& Chapple 2018). In that book, the concept of "fragile governance" is derived from comparing six different cases of Latin American small and medium-sized cities. While the particularities of each case are explained, the aim was to find "repeated instances" to contribute to theoretical debates of local and regional development. The concept seeks to show that local and regional development processes in Latin American peripheral regions take place through governance processes that are often informal and that can easily fail. That is not an exception to the rule; in these cities and regions that is the rule. And, therefore, local and regional development and innovation policies should be designed with that in mind.

\section{PUSHING REGIONAL STUDIES BEYOND ITS BORDERS IV: AN INDUSTRIAL POLICY PERSPECTIVE}

Industrial policy is seen as being back on the agenda after years of neglect (Bailey et al, 2019), with this revived enthusiasm coming at a time of technological transformation.

Strengths. Over the last decade, 'place-based' approaches have increasingly been used to develop regional industrial policies, as dissatisfaction with spatially blind approaches has grown. Place-based approaches emphasise tailoring policy to develop place-specific specialisms and capabilities, on which a region can thrive (Bailey et.al, 2018). Barca (2009), for instance, defines a place-based approach as a long-term strategy aimed at tackling persistent underutilisation of potential and persistent social exclusion in specific places through external interventions and multilevel governance. This place-based focus has begun to be applied to a wide range of policy settings including industrial policy (Bailey et al, 2018), 
research on place-based leadership (Beer et al, 2019), and in managing the impacts of economic shocks (Regional Studies Association, 2019). The place-based approach chimes with modern perspectives on industrial policy more broadly, where industrial policy is seen as a process of discovery requiring strategic collaboration between the private sector and state in unlocking growth opportunities, where policy ideally has the quality of 'embedded autonomy' (see Rodrik, 2008). It is not captured by firms and sectors, but focuses on bringing together actors in a discovery process, where firms and the state learn about underlying costs and opportunities and engage in strategic coordination.

Weaknessses. To be successful, place-based approaches require strengthened local and regional institutions, a need for local stakeholders to be active in order to deliver success, the development of human capital and the critical embrace of innovation (Tomaney, 2010). However, as the Regional Studies Association (2019) notes, government initiatives badged as 'place-based policy' often fall well short, with governments simply relabelling long established programs as 'place-based policy', or only partially innovating. For example, even in the context of the EU's smart specialisation strategy (S3), which is seen as having paved the way in place-based approaches, Gianelle et al (2019) suggests that regions and countries have in reality put in place mechanisms that may circumvent the very rationale of smart specialisation. They note that this could arise from the result of lobbying activities, higher political return from widespread public support measures, a risk-averse attitude of policymakers, and a lack of adequate institutional and administrative capacity that can be observed at national and regional levels. Furthermore, Barzotto et al (2019a/b) argue that S3 projects are more likely to be identified in stronger regions, which boast a strong entrepreneurial talent pool and business networks; as such, S3 policy implementation may inadvertently be aspatial and could exacerbate regional imbalances.

Vision. The arrival of radical and disruptive technologies associated with 'Industry 4.0' or 'Fourth Industrial Revolution', including inter alia artificial intelligence, automation and machine learning, poses challenges for industrial and regional policy and wider socioeconomic cohesion. Recent work stresses that the disruptions brought about by such technologies have the potential to introduce new layers of socio-economic divides (Bailey and De Propris, 2019), with a concomitant call for a more holistic transformative industrial policy that brings together technology, sectors and place. Against this backdrop, the EU risks underestimating the fundamental role that policy and public interventions need to play just as the economy and wider society are embarking on transformations that will shape work, industry, mobility, communications and more for decades ahead. These are times of radical and disruptive change; regional and industrial policies must move towards having a truly transformative power. This could, in the European context, for example, embody S3 strategies with a heightened attention towards the creation and adoption of Fourth Industrial Revolution (FIR) technologies in different regions so as to bring together technology, sectors and place. A transformative industrial policy needs to think beyond sectors alone, and rather identify, nurture and diffuse the key cross-cutting technologies 
(such as digitalisation, the internet of things, robotics and artificial intelligence) that have an enabling role across manufacturing and services.

Opportunities and Challenges. Industrial and regional policy needs to recognise and exploit such technologies by making them accessible to businesses in different regions. Furthermore, a transformative regional industrial policy needs to be developed in a holistic sense (for example on skills, access to finance, clusters, supply chains and innovation) so as to enable policy to be better suited to the distinctive characteristics and advantages of different scales. The latter requires regionally-based industrial development strategies promoting 'related diversification' capitalising on the FIR. Such strategies need to recognise (i) the need to bring together different but related activities in a region via cross cutting FIR technology platforms (such as via Living Labs or digital demonstration hubs) and (ii) the differing potentials of regions to diversify, due to different industrial, knowledge and institutional structures linked to specific regional historical trajectories. This requires tailormade policy actions embedded in, and linked to the specific needs and available resources of regions, starting with the existing knowledge and institutional base in that region. These need to capitalise on region-specific assets, rather than attempting to replicate and apply policies that may have worked in quite different places (Bailey et al, 2018). However, to transform the region's potential based on 'unrelated variety', and to broaden and renew the region's industrial structure by helping it branch into new related activities, policy could also encourage crossovers between manufacturing and service industries and between manufacturing and new technologies. This could come via knowledge transfer mechanisms that connect related and unrelated industries (Grillitsch et al, 2018). Other elements of a transformative regional industrial policy would involve, inter alia, the need for: new skills to be developed and constant re-skilling and up-skilling processes as the FIR progresses; enabling SMEs to have access to funding and finance to embrace digital technologies; recognising and exploiting possibilities to reposition firms, industries and regions on new parts of the global value chain as the value added of manufacturing changes over time; seizing re-shoring opportunities as relocalisation opportunities open up - involving policies to rebuild supply chains in Europe; infrastructure investment to embrace new technologies (e.g. 5G) and so on as part of an holistic regional industrial policy.

\section{PUSHING OFF: GLOBAL STUDIES AND THE BIG REGIONAL CHALLANGES}

This article set out to explore how we push the field of regional studies beyond its present institutional, conceptual and methodological borders. The aim was to stimulate debate around the current state of regional research and how this is sitting in the face of the big global challenges. Identifying strengths and weaknesses in how we approach major themes in regional research, this article affords the space to envision future regional studies and the opportunities and challenges present therein. In this final section we flip the opening proposition of questioning how regional studies is placed to face the big global challenges, 
to posit the importance of global studies in the face of big regional challenges. We argue that the future of regional studies requires approaches which in combination result in the pushing on (by creating), pushing off (by consolidating), pushing back (by critiquing) and pushing forwards (by collectively constructing) the field.

Pushing On. Regional studies may have its origins as a field dominated by geographers and planners but its history as an academic field lay in attracting researchers and combining knowledge and insights from a wide range of disciplines and traditions. Over time regional research has become a broader, multidimensional endeavour, developing into a pluralist forum which showcases diverse perspectives and analytical techniques. Regional thinking has benefitted enormously from bringing the outside in, constantly pushing on to create new knowledge and understanding by embracing ideas derived from different places, using different methods and being explained via different concepts. What these contributions reveal is this approach is needed more than ever. To 'push on' with being open requires us to recognise that most regional research is conducted by people who do not identify themselves, first and foremost, as 'regional' researchers, but who are increasingly brought into conversation because regions are becoming ever more important to (understanding) the world we live in.

Pushing Off. Of course, the danger for any academic field that is open and plural is if it loses its core and becomes simply all things to all people. Gone are the days when regions were self-contained, easily mapped, territorial units, such that today we operate with more permeable, fluid concepts of regions. Then there is the mixed record of regional planning and regional policy. We can also point to the how the study of cities and regions traditionally had a disciplinary home in place and space disciplines (e.g. Planning, Geography) whereas research increasingly takes place in and through interdisciplinary research institutes. What these contributions reinforce is that regions and regional thinking remain central to understanding and responding to global challenges. The history of regions and the 'regional studies project' has always had at its core concerns relating to new and increased social and spatial inequalities resulting from economic and political change. Whatever change has occurred to cause this turbulence, some people and places take advantage and race ahead while others are disadvantaged and left behind. The only difference today is that the stakes are higher, with more people and more places exposed and being impacted than ever before. Regional research is going to be vital to informing public debates and invoking appropriate policy responses. And so it is that regional research is once again spearheading major efforts to provide the type of reliable, robust knowledge necessary to correct the opening of gaps between people and places which are emerging as winners and losers. Pushing off from this intellectual base will be the springboard to ensure the core of what makes regional studies an academic field is consolidated, balancing openness and pluralism with continual discipline and paradigm-formation.

Pushing Back. The notion of pushing beyond borders automatically brings ideas of outward expansion. This is the taken-for-granted, default approach, but there is a lot to be said for 
looking at this in an entirely different way. Rather than pushing regional studies beyond its borders by always looking externally this way requires us to look internally and self-critically. To find innovative solutions to wicked problems it is critical to ask fundamental questions about how we do regional research. Do existing theories and concepts adequately explain present instabilities and new realties, or, do we need to rethink our analytical frameworks? Do existing policies and frameworks help (or hinder) cities and regions, or are there alternatives that we should be promoting? More fundamentally, are we asking the right questions and looking in the right places to find the innovative solutions that enable a more spatially balanced, sustainable and inclusive model of economic growth and political stability? In a 2015 article, Jamie Peck argued as much when he called for researchers "to interrogate and 'stress test' explanatory frameworks, with a view to their ongoing and critical reconstruction" (Peck, 2015: 175 original emphasis). Arguably less fashionable than the quest for newness, going forwards sometimes requires us to go back first. None of the contributions here argue for throwing the baby out with the bathwater and starting over again. Rather they speak to pushing regional studies beyond its borders by (re)asserting certain fundamentals through a process of engaging in, and responding to, critique.

Pushing Forward. Regional studies is and continues to be an expanding academic field. Long gone are the days when regional studies could be characterised as a field dominated by a small cadre of fairly like-minded contributors. Regional studies retain a strong core focus but difference and diversity are present watchwords vi. We must be conscious that in pushing forward there is always the risk of subdivision, of creating new internal divides - real or otherwise - by pigeonholing research as this or that. It can certainly appear increasingly difficult for expanding academic fields to find things that unite them, and people can all agree on. Regional Studies has, for over fifty years now, had this mix of qualitative and quantitative, political and economic, cities and regions, urban and rural, winners and losers, advocates and critics. Dialogue among critical researchers interested in regions has always been central to this journal and the wider field. But perhaps we are reaching (maybe have even reached) that point where it is increasingly difficult to say where the borders of regional studies actually are to even contemplate the notion of pushing regional studies beyond its borders. What regional studies is to one person will be different to another so do we need to know where the borders are? Or, should we be thinking about it in an entirely different way altogether? Either way, pushing forwards must involve a collective constructing of the field. This is something which requires a greater awareness of what the focal points are for regional studies. In this way, what this article points towards is perhaps it is less about recognising how regional studies is sitting in the face of the big global challenges, and more about recognising the opportunities afforded by engaging in an increasingly global field of studies where dialogue and debate will be determined more by the big regional challenges than necessarily regional studies per se. 



\section{REFERENCES}

Anguelovski I (2016). From toxic sites to parks as (green) LULUs? New challenges of inequity, privilege, gentrification, and exclusion for urban environmental justice. Journal of Planning Literature, 31, 23-36.

Anguelovski I, Chu E and Carmin J (2014). Variations in approaches to urban climate adaptation: experiences and experimentation from the global south. Global Environmental Change, 27, 156-167.

Anguelovski I, Connolly J and Brand A (2018). From landscapes of utopia to the margins of the green urban life: for whom is the new green city? City, 22, 417-436.

Anguelovski I, Connolly J, Garcia Lamarca M, Cole H and Pearsall H (2019) New scholarly pathways on green gentrification: What does the urban "green turn" mean and where is it going? Progress in Human Geography, 1-23, DOI: 10.1177/0309132518803799

Anguelovski I, Shi L, Chu E, Gallagher D, Goh K, Lamb Z, Reeve K and Teicher H (2016). Equity impacts of urban land use planning for climate adaptation: critical perspectives from the global north and south. Journal of Planning Education and Research, 36, 333-348.

Bailey D, Pitelis C and Tomlinson P (2018). A place-based developmental regional industrial strategy and/for sustainable capture of co-created value, Cambridge Journal of Economics, 42, 1521-1542.

Bailey D, Glasmeier A, Tomlinson P and Tyler P (2019). Industrial policy: new technologies and transformative innovation policies? Cambridge Journal of Regions, Economy and Society, 12, 169-177.

Bailey D and De Propris L (2019). Industry 4.0, regional disparities and transformative industrial policy, in Barzotto M, Corradini C, Fai F, Labory S and Tomlinson P (eds) Revitalising Lagging Regions: Smart Specialisation and Industry 4.0. London: Routledge.

Barca F (2009). An Agenda for a Reformed Cohesion Policy: A Place Based Approach to Meeting European Union Challenges and Expectations, DG Regio, available at: http://www.interacteu.net/downloads/1224/An Agenda for a Reformed Cohesion Policy.pdf

Barnes T and Sheppard E (2010). 'Nothing includes everything': towards engaged pluralism in Anglophone economic geography. Progress in Human Geography, 34, 193-214.

Brenner, N. (2019). New Urban Spaces: Urban Theory and the Scale Question. Oxford: Oxford University Press.

Barzotto M, Corradini C, Fai F, Labory S and Tomlinson P (2019a). Revitalising Lagging Regions: Smart Specialisation and Industry 4.0. London: Routledge.

Barzotto M, Corradini C, Fai F, Labory S and Tomlinson P (2019b). Enhancing innovative capabilities in lagging regions: an extra-regional collaborative approach to RIS3, Cambridge Journal of Regions, Economy and Society, 12, 213-232

Bulkeley H, Edwards $\mathrm{G}$ and Fuller S (2014). Contesting climate justice in the city: examining politics and practice in urban climate change experiments. Global Environmental Change, 25, 31-40.

Chapple K, Montero S and Sosa O (2012). Evolving regionalismos: Latin American regions in the 21st century. Regional Development Dialogue, 33, iii-xv. 
Davoudi S (2007). Polycentricity: panacea or pipedream, in Cattan, N. (ed.) Cities and Networks in Europe. A Critical Approach of Polycentrism. Montrouge: John Libbey, pp. 65-74.

Delgado M, Porter M, and Stern S (2016). Defining clusters of related industries. Journal of Economic Geography, 16 (1), 1-38.

Delgado M (2018). Firms in context: internal and external drivers of success, in G Clark, M Feldman, M Gertler and D Wójcik (eds.), The New Oxford Handbook of Economic Geography, Oxford: Oxford University Press, pp.324-344.

Delgado M and Mills K (2018). A new categorization of the US economy: the role of supply chain industries in innovation and economic performance. HBS Research Paper No. 18-068.

Delgado $M$ and Murray $F$ (2018). Catalysts for gender inclusion in innovation: the role of universities and their top inventors. MIT Working Paper.

Derudder B and Taylor PJ (2018). Central flow theory: comparative connectivities in the world-city network. Regional Studies, 52, 1029-1040.

Escobar A (2008). Territories of Difference: Place, Movements, Life, Redes. Durham: Duke University Press.

Gascon M, Triguero-Mas M, Martínez D, Dadvand $P$, Rojas-Rueda $D$, Plasència $A$ and Nieuwenhuijsen $M$ (2016). Residential green spaces and mortality: a systematic review. Environment International, 86, 60-67.

Gianelle G, Guzzo F and Mieszkowski K (2019). Smart specialisation: what gets lost in translation from concept to practice?, Regional Studies, 1-12, DOI: 10.1080/00343404.2019.1607970

Gibson-Graham JK (2016). Building community economies: women and the politics of place, in Harcourt W (ed.) The Palgrave Handbook of Gender and Development. London: Palgrave Macmillan, pp.287-311.

Guilluy C (2016). La France Périphérique: Comment on a Sacrifié les Classes Populaires [Peripheral France: How we Sacrificed the Popular Classes]. Paris: Flammarion.

Intergovernmental Panel on Climate Change (2014). Synthesis Report. Contribution of Working Groups I, II and III to the Fifth Assessment Report of the Intergovernmental Panel on Climate Change. Geneva: IPCC.

Krugman P (2011). The new economic geography, now middle-aged. Regional Studies, 45, 17.

Li Y \& Phelps N (2017). Knowledge polycentricity and the evolving Yangtze River Delta megalopolis. Regional Studies, 51, 1035-1047.

Mahutga M, Ma X, Smith D and Timberlake M (2010). Economic globalisation and the structure of the world city system: the case of airline passenger data. Urban Studies, 47, 1925-1947.

Martin R and Sunley P (2015). Towards a developmental turn in evolutionary economic geography? Regional Studies, 49(5), 712-732.

Meijers E, Burger $M$ and Hoogerbrugge $M$ (2016). Borrowing size in networks of cities: city size, network connectivity and metropolitan functions in Europe. Papers in Regional Science, 95, 181-198.

Meerow S and Newell J(2017). Spatial planning for multifunctional green infrastructure: growing resilience in Detroit. Landscape and Urban Planning, 159, 62-75. 
Montero S (2019). Leveraging Bogotá: sustainable development, global philanthropy and the rise of urban solutionism. Urban Studies, 1-99, DOI: $10.1177 / 0042098018798555$.

Montero S (forthcoming). Repensando el Desarrollo Económico desde Colombia. Bogotá: Ediciones Uniandes.

Montero S and Chapple K (2018). Fragile Governance and Local Economic Development: Theory and Evidence from Peripheral Regions in Latin America. London: Routledge.

Nightingale A, Eriksen S, Taylor M, Forsyth T, Pelling M, Newsham A, Boyd E, Brown K, Harvey $B$ and Jones $L$ (2019). Beyond technical fixes: climate solutions and the great derangement. Climate and Development, 1-10, DOI: 10.1080/17565529.2019.1624495

Paasi A, Harrison J and Jones M (2018). New consolidated regional geographies, in Paasi A, Harrison J and Jones M (eds.) Handbook on the Geographies of Regions and Territories, Edward Elgar: Cheltenham, pp. 1-20.

Peck J (2015). Cities beyond compare? Regional Studies, 49, 160-182.

Pelling M, O'Brien K and Matyas D (2015). Adaptation and transformation. Climatic Change, 133, 113-127.

Pike A, Rodríguez-Pose A and Tomaney J (2016). Local and Regional Development. London: Routledge

Porter M (2000). Location, clusters, and company strategy, in G Clark, M Feldman and M Gertler (eds.) The Oxford Handbook of Economic Geography, Oxford: Oxford University Press, pp.253-274.

Robinson J (2002). Global and world cities: a view from off the map. International Journal of Urban and Regional Research, 26, 531-554.

Robinson J (2016a). Comparative urbanism: new geographies and cultures of theorizing the urban. International Journal of Urban and Regional Research, 40, 187-199.

Robinson J (2016b). Theorizing the global urban with 'global and world cities research': beyond cities and synechdoche. Dialogues in Human Geography, 6, 268-272.

Robinson J and Roy A (2016). Debate on global urbanisms and the nature of urban theory. International Journal of Urban and Regional Research, 40, 181-186.

Rodrik D (2008). One Economics, Many Recipes: Globalization, Institutions, and Economic Growth. Princeton: Princeton University Press.

Rodríguez-Pose A (2018). The revenge of the places that don't matter (and what to do about it). Cambridge Journal of Regions, Economy and Society, 11, 189-209.

Romero-Lankao P, Bulkeley H, Pelling M, Burch S, Gordon D, Gupta J, Johnson C, Kurian P, Lecavalier E and Simon D (2018). Urban transformative potential in a changing climate. Nature Climate Change, 8, 754-756.

Roy A (2009). The 21st-century metropolis: new geographies of theory. Regional Studies, 43, 819-830.

Rozenblat C (2010). Opening the black box of agglomeration economies for measuring cities' competitiveness through international firm networks. Urban Studies, 47, 2841-2865.

Regional Studies Association (2019). Place Based Leadership. Available at: http://placeleadershipnetwork.org/rsa-policy-expo-enabling-best-practice-in-placebased-policy

Salvini $M$ and Fabrikant S (2016). Spatialization of user-generated content to uncover the multirelational world city network. Environment and Planning B, 43, 228-248.

Scott AJ (2019). City-regions reconsidered. Environment and Planning A, 51, 554-580. 
Scott AJ and Storper M (2015). The nature of cities: the scope and limits of urban theory. International Journal of Urban and Regional Research, 39, 1-16.

Shi L, Chu E, Anguelovski I, Aylett A, Debats J, Goh K, Schenk T, Seto K, Dodman D, Roberts D, Roberts T and Vandeveer S (2016). Roadmap towards Justice in urban climate adaptation research. Nature Climate Change, 6, 131-187.

Sovacool B, Linnér B-O and Goodsite M (2015). The political economy of climate adaptation. Nature Climate Change, 5, 616-618.

Taylor PJ (1994). The state as container: territoriality in the modern world-system. Progress in Human Geography, 18, 151-162.

Taylor PJ and Lang R (2004). The shock of the new: 100 concepts describing recent urban change. Environment and Planning A, 36, 951-958.

Taylor PJ, Derudder B, Hoyler M and Ni P (2013). New regional geographies of the world as practised by leading advanced producer service firms in 2010. Transactions of the Institute of British Geographers, 38, 497-511.

Tomaney J (2010). Place-Based Approaches to Regional Development: Global Trends and Australian Implications. Sydney: Australian Business Foundation.

Van Meeteren M, Derudder B and Bassens D (2016). Can the straw man speak? An engagement with postcolonial critiques of 'global cities research'. Dialogues in Human Geography, 6, 247-267.

Van Meeteren M, Bassens D and Derudder B (2016b). Doing global urban studies: on the need for engaged pluralism, frame switching, and methodological cross-fertilization. Dialogues in Human Geography, 6, 296-301.

Wu F (2016). China's emergent city-region governance: a new form of state spatial selectivity through state-orchestrated rescaling. International Journal of Urban and Regional Research, 40, 1134-1151.

Yashar D (2015). Does race matter in Latin America: how racial and ethnic identities shape the region's politics. Foreign Affairs, 94, 33-40.

Zhang W, Derudder B, Wang J and Shen W (2018). Regionalization in the Yangtze River Delta, China, from the perspective of inter-city daily mobility. Regional Studies, 52, 528-541.

Zhang J and Peck J (2016). Variegated capitalism, Chinese style: regional models, multi-scalar constructions. Regional Studies, 50(1), 52-78. 


\section{ACKNOWLEDGEMENTS}

This paper originates from the opening plenary panel session at the 2019 Regional Studies Association Annual Conference held in Santiago de Compostela, Spain, from 5-7 June. The authors thank the RSA and local organisers for the invitation to organise and participate in this panel, and the audience for their contributions.

\section{ENDNOTES}

\footnotetext{
' The cluster specialisation of these candidate cities can be accessed at the U.S. Cluster Mapping Project (USCMP) at http://www.clustermapping.us/. The USCMP underlying cluster definitions are developed by Delgado et al. (2016).

ii Available at http://publichealth.lacounty.gov/chronic/docs/Parks\%20Report\%202016-rev 051816.pdf

iii Available at https://www.vox.com/energy-and-environment/2019/4/9/18300797/barcelona-spainsuperblocks-urban-plan and https://ajuntament.barcelona.cat/ecologiaurbana/en/what-we-do-andwhy/quality-public-space/superblocks

${ }^{i v}$ Available at https://www.boston.gov/departments/environment/resilient-boston-harbor

${ }^{\vee}$ Available at https://www.wbur.org/earthwhile/2019/05/02/moakley-park-east-boston-climate-resiliency

vi We only have to look over the past decade to see the institutional response as the Regional Studies Association went from having one journal for forty years - Regional Studies - to a suite of five as Spatial Economic Analysis (2006), Territory, Politics, Governance (2013), Regional Studies, Regional Science (2014) and Area Development \& Policy (2016) were added to see one indication of this expansion of the field.
} 